\title{
PEMBERDAYAAN KELOMPOK SADAR WISATA (POKDARWIS) TIRAM TAMBUN DALAM MENGEMBANGKAN DESA WISATA MENTAWIR KABUPATEN PANAJAM PASER UTARA
}

\author{
Yogiana Mulyani, Saiful Ghozi, Henry Winnarko \\ Politeknik Negeri Balikpapan \\ Email:yogiana.mulyani@poltekba.ac.id
}

\begin{abstract}
Mentawir Tourism Village is a tourism village located in Penajam Paser Utara, East Kalimantan. This Tourism Village has "Pokdarwis" (Tourism Awarness Group) which has been formally confirmed by the head Department of Culture and Tourism in Penajam Paser Utara on August 7, 2019. However, the development of the Mentawir Tourism Village has not been maximized so it is necessary to empower more of the Pokdarwis Tiram Tambun to strengthen the management and promotion of the Mentawir Tourism Village. Several problems occurred in the Mentawir Tourism Village such as the lack of ability to manage the Pokdarwis Tiram Tambun institutions that were ineffective, inefficient and intransparent. They are also incapable to promote through various media and product of breakfast menu in their own homestay. The approachment methods used in this activities including socialization, training and mentoring. The results of these activities including the knowledge and skills of the management and members of the Pokdarwis Tiram Tambun to increase or to improve in terms of effective, efficient and transparent management through improving the administration or organizational bookkeeping, the development of potential tourism in the Mentawir village can be mapped through tourism products in the form of tour packages that will be offered to the tourists, as well as increasing the promotion of the Mentawir itself through various social media in order to increase the number of tourists visiting there and improvement skill from homestay owners in producing breakfast dishes
\end{abstract}

Keywords: Tourist Village; Mentawir; Pokdarwis; Empowering

\begin{abstract}
Abstrak
Kelurahan Mentawir merupakan kawasan berpotensi wisata yang terletak di Kecamatan Sepaku, Kabupaten Penajam Paser Utara, Kalimantan Timur. Potensi wisata didaerah ini dikelola oleh Kelompok Sadar Wisata (Pokdarwis) Tiram Tambun yang telah mendapatkan pengukuhan secara resmi oleh Kepala Dinas Kebudayaan dan Pariwisata Kabupaten Panajam Paser Utara pada tanggal 7 Agustus 2019. Namun dalam pengembangan Wisata Mentawir belum maksimal sehingga perlu dilakukan pemberdayaan Pokdarwis untuk memperkuat pengelolaan dan promosi Desa Wisata Mentawir. Beberapa permasalahan di Wisata Mentawir antara lain kurangnya kemampuan dalam mengelola kelembagaan Pokdarwis yang efektif, efisien dan transparan, kurangnya kemampuan dalam melakukan promosi melalui berbagai media, serta kurangnya ketrampilan dalam pengolahan menu makan pagi di homestay. Metode pendekatan yang dilakukan dalam kegiatan ini antara lain sosialisasi, pelatihan dan pendampingan. Hasil dari kegiatan memberikan dampak bertambahnya pengetahuan dan keterampilan pengurus dan anggota Pokdarwir Tiram Tambun yang efektif, efesien dan transparan. Kegiatan pendampingan ini juga menghasilkan pemetaan paket-paket wisata yang akan ditawarkan kepada wisatawan. Selain itu, hasil yang dicapai dibidang pemasaran digital adalah meningkatnya atau bertambahnya promosi desa wisata Mentawir melalui berbagai media sosial dalam rangka mensosialisasikan potensi Mentawir kepada wisatawan, serta bertambahnya ketrampilan dari pengelolaan dan pelayanan di homestay.
\end{abstract}

Kata Kunci: Desa Wisata; Mentawir; Pokdarwis; Pemberdayaan 


\section{PENDAHULUAN}

Mentawir merupakan kawasan dengan letak geografis yang jauh terpencil, tingkat pendidikan masyarakat yang rendah, dan tingkat ekonomi masyarakatnya yang masih tergantung dengan sumberdaya alam. Mentawir hanya berpenduduk $211 \mathrm{KK}, 675$ jiwa dan terdiri dari 4 Rukun Tetangga (RT). Daerah tersebut memiliki potensi alam yang masih terjaga. Sehingga mengundang beberapa pengunjung dari luar daerah untuk berkunjung, baik kunjungan wisata maupun kunjungan penelitian dari dalam dan luar negeri.

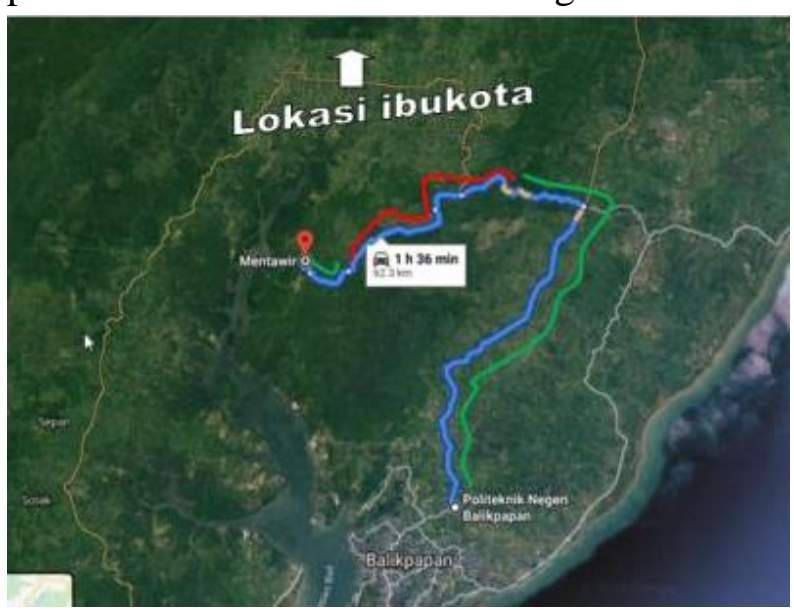

Mentawir berjarak sekitar $66 \mathrm{~km}$ dari Kota Balikpapan via transportasi darat Balikpapan-Sepaku-Mentawir, dengan jarak tempuh kurang lebih 1 jam 45 menit sd 2 jam. Selain itu dapat juga menggunakan transportasi laut dengan menggunakan speedboat dengan jarak tempuh 45 menit melalui pelabuhan Semayang Balikpapan melewati Teluk Balikpapan. Jalur darat dan gambaran sebaran penduduk terihat dalam gambar 1 berikut.

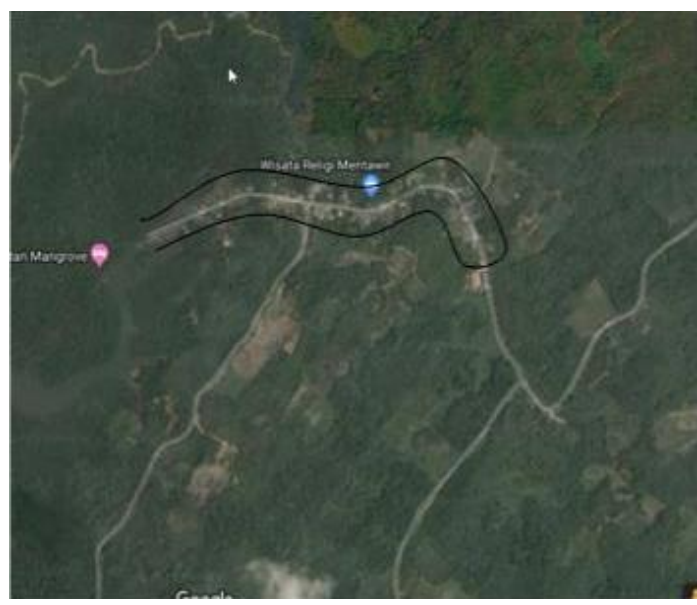

Gambar 1. a. Rute perjalanan dari PT ke mitra jalan— (aspal bagus - jalan rusak - ) b. Gambaran penyebaran penduduk mitra

Dari empat RT yang ada di Mentawir, RT 01 terletak paling ujung yang merupakan daerah pesisir/ tepi teluk Balikpapan, ditandai adanya dermaga dan kawasan hutan mangrove, sekaligus pintu masuk Kelurahan Mentawir dari jalur laut dan teluk Balikpapan. Kawasan hutan mangrove yang berada di aliran sungai Tiram
Tambun inilah yang menjadi daya tarik wisata utama di sana yang sering dikunjungi oleh para wisatawan yang berasal dari lain. Dari mulai wisata memancing, rombongan siswa sekolah, hingga wisata regular masyarakat. Untuk wisatawan asing biasanya yang berkunjung adalah wisatawan minat khusus, yakni para peneliti. 


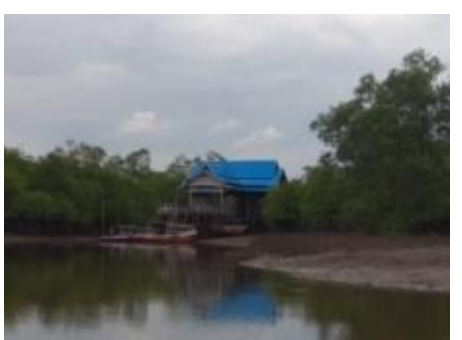

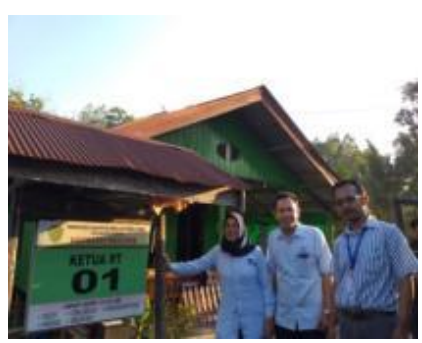

b

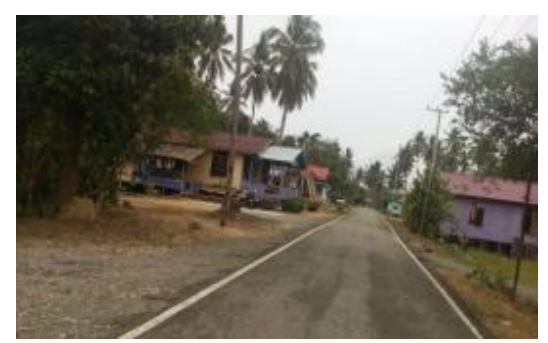

c

Gambar 2. Survey Analisis Situasi Kawasan Mentawir

Pengembangan fasilitas yang ada sejauh ini hanya dari bantuan CSR PT Inhutani I tahun 2018 selaku pemilik konservasi kawasan hutan mangrove. Fasilitas yang dibangun di area tersebut seperti mushola, warung, dan jembatan (bridging). Jembatan (bridging) sepanjang 500 meter ini dibuat untuk memudahkan para wisatawan menikmati keindahan dan berbagai jenis tumbuhan mangrove sambil melihat berbagai macam satwa yang ada di dalamnya. Salah satunya adalah bekantan yang merupakan satwa endemik Kalimantan. Pengunjung juga dapat menyelusuri kawasan hutan mangrove dengan perahu yang sekaligus dapat difungsikan sebagai sarana memancing serta pengamatan flora dan fauna sekitar hutan Mangrove. Karena minimnya tindak lanjut pengembangan pengelolaan potensi wisata dari instansi terkait. Sejauh ini pengelolaan dilakukan secara swadaya oleh Pokdarwis "TIRAM TAMBUN" yang terbentuk sejak tanggal 15 Oktober 2015, dan mendapat pendampingan tim PPM dana DIPA Politeknik Negeri Balikpapan sejak tahun 2018.

Jejak Politeknik Negeri Balikpapan (Poltekba) melalui tim dari Jurusan Perhotelan pada tahun 2019 telah ada melalui pendampingan di Desa Wisata Mentawir dengan mengidentifikasi potensi kepawisataaan dan pengenalan fasilitas homestay di kawasan Mentawir (Mulyani, 2021). Hasil dari kegiatan pendampingan tersebut didapatkan bahwa kawasan Mentawir dipandang layak untuk dikembangkan sebagai desa wisata. Setelah melalui pendampingan pendanaan internal DIPA Poltekba dan berkolaborasi dengan Kementerian Pariwisata RI, akhirnya Pokdarwis "Tiram Tambun" pendapatkan pengukuhan secara resmi oleh Kepala Dinas Kebudayaan dan Pariwisata Kabupaten Panajam Paser Utara pada tanggal 7 Agustus 2019 yang tertuang dalam SK Nomor: 188.48/050/DISBUDPAR/VIII/2019 sebagai pengelola dari Desa Wisata Mentawir.

Dalam konsep pengembangan desa wisata yang dimulai dari mulai tahap rintisan, berkembang, maju dan mandiri didasarkankan pada beberapa pemenuhan indikator yang telah ditetapkan. Pada kawasan Mentawir masih terdapat beberapa kekurangan yang dimiliki oleh Desa Wisata Mentawir antara lain, kurangnya kemampuan dalam mengelola 
kelembagaan Pokdarwis Tiram Tambun yang efektif, efisien dan transparan serta kurangnya kemampuan dalam melakukan promosi melalui berbagai media. Oleh karena itu Politeknik Negeri Balikpapan melakukan kegiatan pengabdian lanjutan dengan melaksanakan kegiatan pendampingan desa wisata dalam hal memperkuat kepengelolaan dan promosi dari Desa Wisata Mentawir. Tujuan dari kegiatan pengabdian kepada masyarakat ini yakni memberikan solusi-solusi terhadap permasalahan yang dihadapi oleh mitra yakni dalam hal menyamakan persepsi antara pengurus dan anggota Pokdarwir Tiram Tambun mengenai pengelolaan kelembagaannya yang efektif, efesien dan transparan melalui pembenahan administrasi atau pembukuan organisasi, melakukan pemetaan terhadap potensi kepariwisataan di Mentawir yang akan dikembangkan melalui produk wisata dalam bentuk paket-paket wisata yang akan ditawarkan kepada wisatawan, serta meningkatkan promosi desa wisata mentawir melalui berbagai media sosial untuk meningkatkan jumlah kunjungan wisatawan ke desa wisata Mentawir.

\section{TINJAUAN LITERATUR}

\section{Pariwisata Berbasis Komunitas}

Untuk mecapai tujuan dari kegiatan pengabdian kepada masyarakat ini menggunakan beberapa metode pelaksanaan. Adapun metode pelaksanaan yang telah dilakukan berikut. Desa Wisata merupakan suatu daerah tujuan wisata atau disebut pula destinasi pariwisata yang mengintegrasikan daya tarik wisata, fasilitas umum, fasilitas pariwisata, aksesibilitas yang disajikan dalam suatu struktur kehidupan masyarakat yang menyatu dengan tata cara dan tradisi yang berlaku (Tim Master Trainer Desa Wisata, 2019). Sedangkan menurut Muljadi (2012) Desa Wisata merupakan pengembangan suatu wilayah desa yang pada dasarnya tidak merubah apa yang sudah ada akan tetapi lebih cenderung kepada pengembangan potensi desa yang ada dengan melakukan pemanfaatan kemampuan unsur-unsur yang ada di dalam desa yang berfungsi sebagai atribut produk wisata dalam skala yang kecil menjadi rangkaian aktivitas atau kegiatan pariwisata dalam mampu menyediakan serta memenuhi serangkaian kebutuhan perjalanan wisata baik dari aspek daya tarik maupun sebagai fasilitas pendukung.

Pembangunan pariwisata berbasis masyarakat merupakan salah satu konsep yang menjelaskan tentang pentingnya peranan komunitas dalam pembangunan pariwisata atau biasa disebut dengan Community Based Tourism (CBT) (Mulyani, 2019). Secara konsep, prinsip dasar pembangunan pariwisata berbasis masyarakat merupakan dengan menempatkan masyarakat sebagai komponen utama yang dapat dilakukan untuk pemberdayaan masyarakat dalam berbagai macam kegiatan kepariwisataan, sehingga manfaat dari kepariwisataan seluruhnya dapat diperuntukkan bagi masyarakat, dimana masyarakat atau penduduk setempat memiliki peranan penting dan utama dalam pengambilan keputusan 
mempengaruhi dan memberi manfaat terhadap kehidupan dan lingkungan mereka (Prasiasa Oka Putu Dewa, 2012).

Dalam UU RI No.10 tahun 2009 tentang Kepariwisataan disebutkan bahwa daya tarik wisata adalah segala sesuatu yang memiliki keunikan, keindahan, dan nilai yang berupa keanekaragaman kekayaan alam, budaya dan hasil buatan manusia yang menjadi sasaran atau kunjungan wisatawan. Kelompok Sadar Wisata Menurut buku panduan Kelompok Sadar Wisata (Rahim , 2012) adalah sebagai penggerak Sadar Wisata dan Sapta Pesona di lingkungan objek pariwisata. Sebagai Mitra Pemerintah dan pemerintah daerah (kabupaten/kota) dalam upaya perwujudan dan pengembangan sadar wisata di daerah tersebut. Fungsi dari Kelompok Sadar
Wisata yaitu sebagai penggerak sadar wisata dan Sapta Pesona, sebagai mitra pemerintah dalam mewujudkan dan pengembangan wisata di daerah tersebut. Untuk pendekatan pendampingan desa wisata akan lebih optimal melalui Lembaga Pokdarwis.

Kelompok Kelompok Sadar Wisata (Pokdarwis) Tiram Tambun ini dibentuk atas inisiasi dari PT.Inhutani I berkolaborasi dengan tim PPM Dana Internal Politeknik Negeri Balikpapan dalam pendampingan pengembangannya. Penamaan Tiram Tambun diambil dari nama sungai yang berada di kawasan hutan mangrove Mentawir. Pengukuhan.

Struktur organisasi pokdarwis Tiram Tambun dapat dilihat pada gambar 5 di bawah ini:

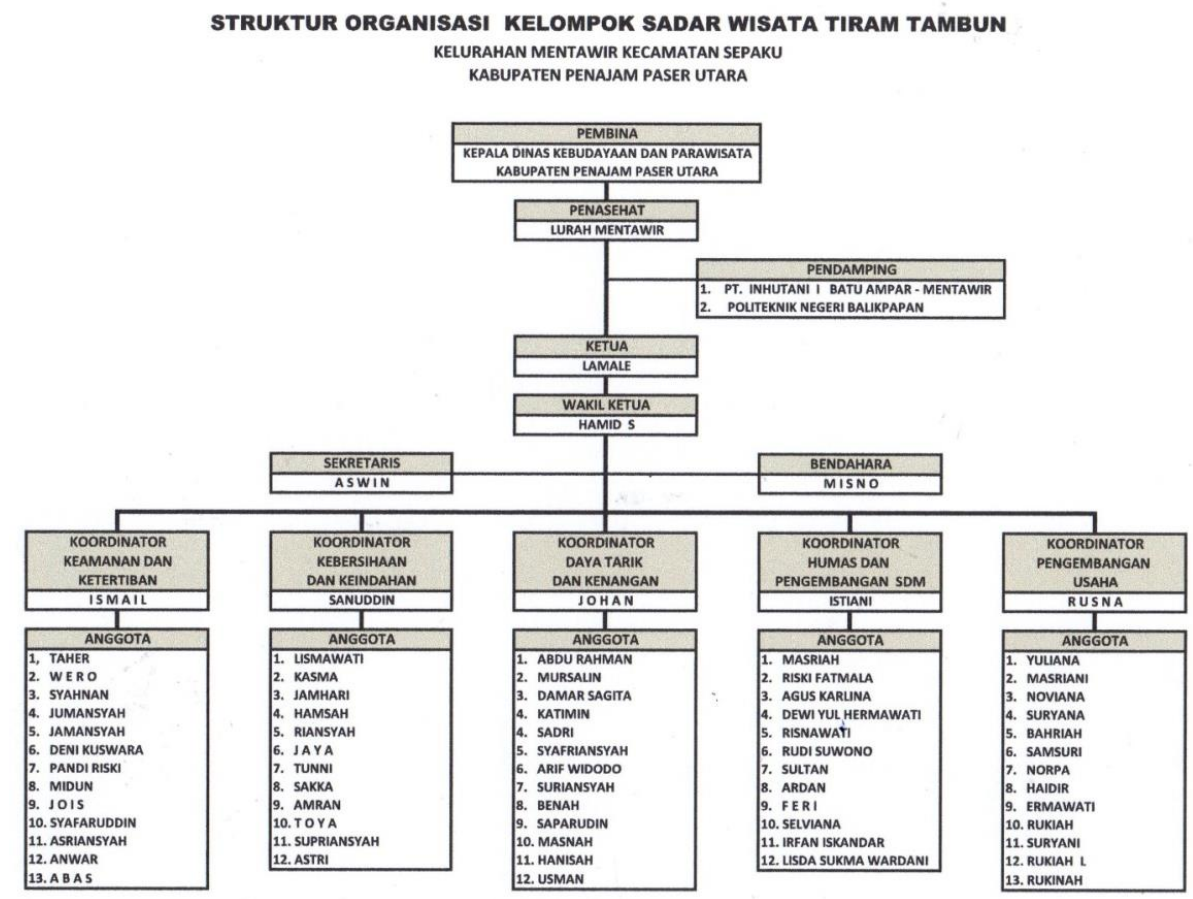

Gambar 3. Struktur Organisasi Pokdarwis Tiram Tambun di desa mentawir (sumber dokumen SK Disbudpar PPU Nomor: 188.48/050/DISBUDPAR/VIII/2019) 


\section{METODE PELAKSANAAN}

Untuk mecapai tujuan dari kegiatan pengabdian kepada masyarakat ini menggunakan beberapa metode pelaksanaan. Adapun metode pelaksanaan yang telah dilakukan berikut.

\section{a. Sosialisasi}

Kegiatan sosialiasi perlu dilakukan agar masyarakat yang didampingi dapat memahami dampak yang akan timbul dari adanya pengembangan desa wisata di daerah masyarakat tersebut. Adapun tujuan dari kegiatan sosialisasi kegiatan ini bertujuan untuk memberikan informasi dan gambaran kepada mitra khususnya calon penerima manfaat dan aparat desa tentang tujuan dan rangkaian program kegiatan secara keseluruhan. Memberikan motivasi kepada seluruh peserta agar dapat mengikuti pelaksanaan kegiatan program dengan kesungguhan dan tanggungjawab. Melakukan kesepakatan mengenai rencana waktu pelaksanaan kegiatan terutama untuk pelatihan, pendampingan, monitoring dan evaluasi.

b. Pelatihan

Pelatihan ditujukan sebagai upaya mengembangkan program edukasi kepada masyarakat melalui pola-pola yang lebih berorientasikan pada peningkatan kualitas sumber daya manusia. Kegiatan ini merupakan inti dari kegiatan pengabdian kepada masyarakat.

c. Pendampingan

Kegiatan pendampingan dilakukan setelah pelatihan dalam bentuk coaching dengan memberikan pengarahan dan penilaian terhadap penerapan dari hasilhasil pelatihan yang sudah diberikan.

Tabel 1. Rencana Kerja dan Target Luaran Kegiatan

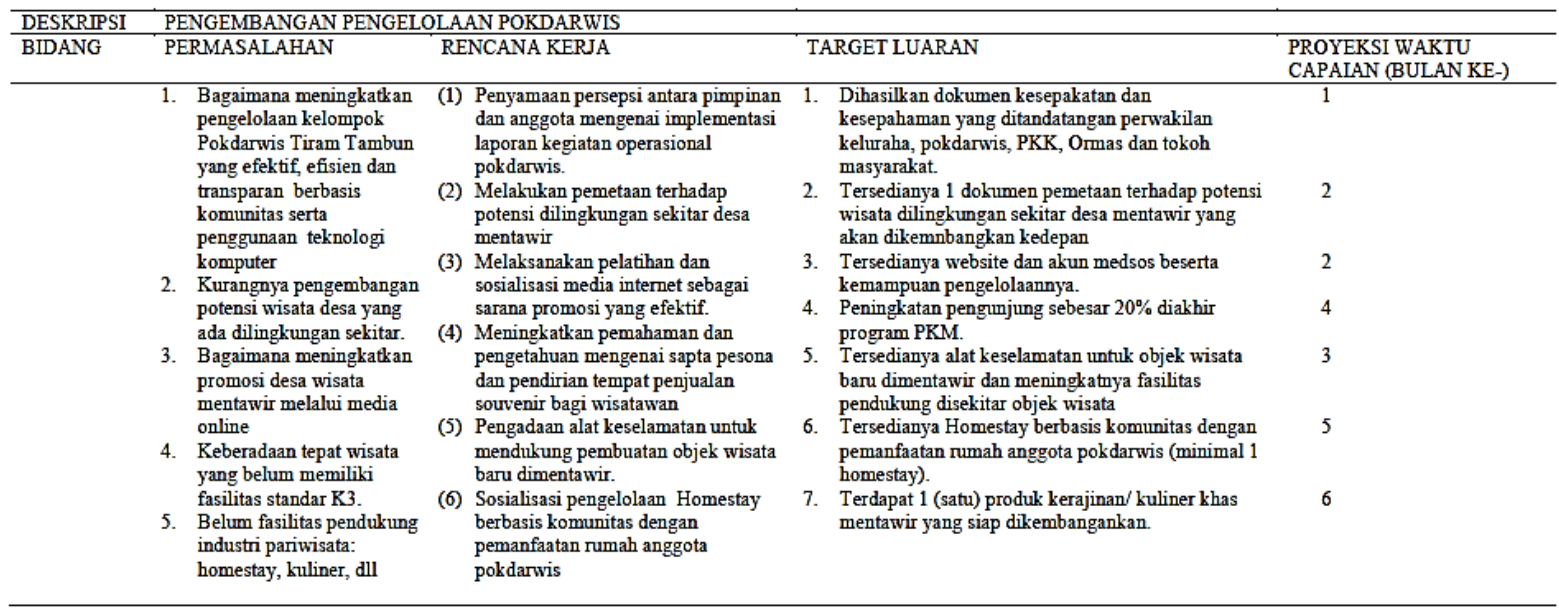

4. HASIL DAN PEMBAHASAN

Dari pelaksanaan kegiatan pengabdian masyarakat yang telah dilakukan, luaran-luaran (output) yang telah dicapai yakni beberapa kegiatan yang sudah berjalan sebagai berikut. 


\section{Kegiatan Tahap 1}

a. Sosialisasi penyamaan persepsi pokarwis, perangkat desa, tokoh masyarakat.

b. Kegiatan ini dilakukan dalam bentuk kegiatan koordinasi dengan pengurus Pokdarwis "Tiram Tambun", perangkat kelurahan dan tokoh masyarakat pada hari
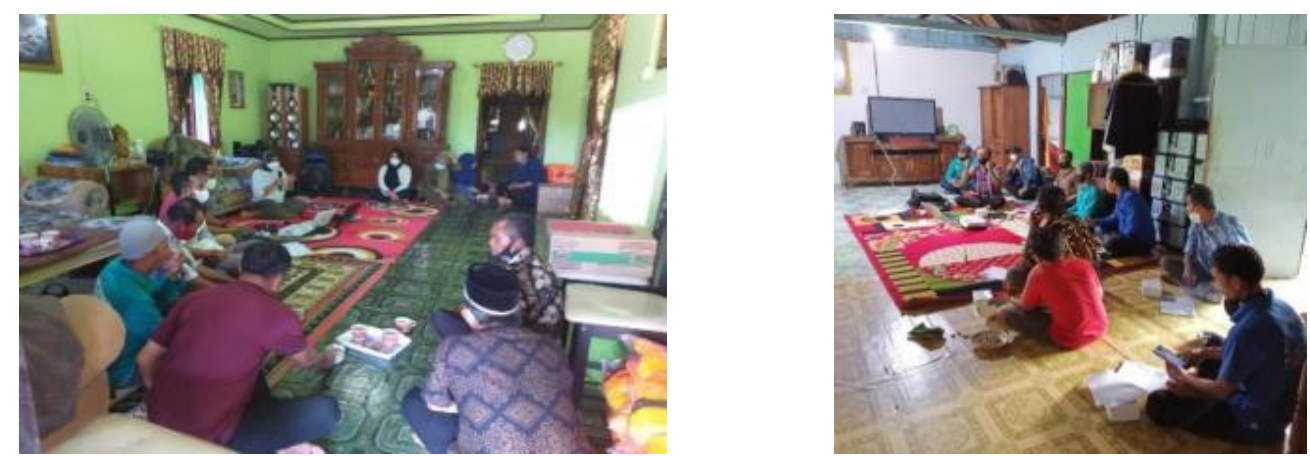

Gambar 4. Kegiatan Sosialiasi dan Koordinasi

c. Pemahaman Paket Wisata

Kegiatan ini dilaksanakan pada hari Minggu tanggal 11 Juli 2021 yang melibatkan pengurus dan anggota Pokdarwis "Tiram Tambun" sebanyak

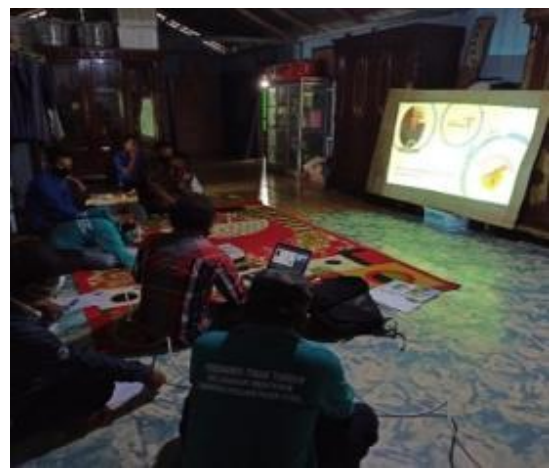

Sabtu tanggal 19 Juni 2021 bertempat di rumah ketua Pokdarwis "Tiram Tambun". Output dari kegiatan sosialisasi ini yakni jadwal untuk pelaksanaan kegiatan pengabdian kepada masyarakat terutama untuk pelatihan dan pendampingan.
30 orang dan dibagi menjadi 3 kelompok kegiatan yang terdiri dari:

1) Kelompok pengelola dan pemandu desa wisata untuk pelatihan dengan materi paket wisata dan pemandu wisata.

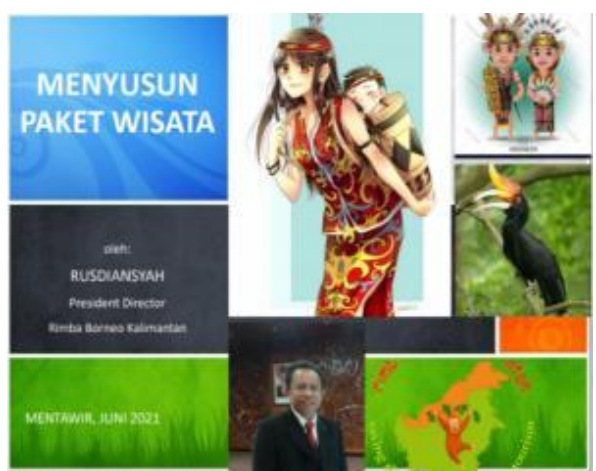

Gambar 5. Sosialisasi Potensi Paket Wisata

Pelatihan ini dalam rangka memberikan pengetahuan dan ketrampilan dalam hal membuat atau mengemas atraksi-atraksi wisata yang ada di Desa Wisata Mentawir untuk dijadikan produk wisata dalam bentuk paket-paket wisata yang bisa dijual kepada para 
wisatawan langsung atau melalui tour-tour operator.

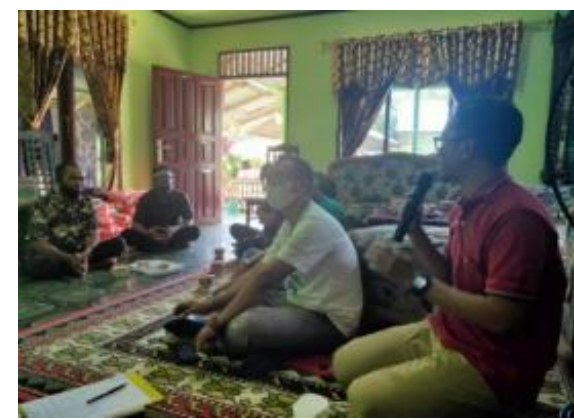

2) Kelompok pengelola pemasaran /promosi untuk pelatihan digital branding melalui media social.

Gambar 6. Sosialisasi dan Diskusi tentang Digital Marketing

Pelatihan ini dalam rangka memberikan penguatan kemampuan komunitas Desa Wisata Mentawir dibidang digita branding. Materi yang diberikan terkait digital branding desa wisata melalui media sosial instragram bisnis, $F B$ page, dan channel youtube. Kegiatan ini melibatkan pemuda dan pemudi desa Mentawir yang tergabung dalam Pokdarwis. Target dari kegiatan ini selain peningkatan kemampuan digital branding, secara teknis akun IG minimal sudah mendapatkan follower

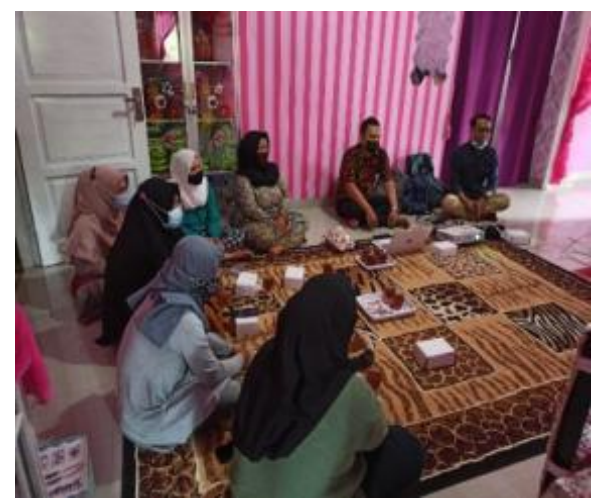

dengan postingan foto update standar branding lokasi wisata setiap 1 minggu sekali. Selain itu, dibuatkan akun youtube khusus desa Mentawir yang berisi materi lokasi desa Mentawir yang dikelola dengan baik dan menargetkan minimal 1 posting setiap 2 minggu, dan di akhir kegiatan pendampingan sudah memiliki 100 subriber.

3) Kelompok pengelola homestay dengan untuk pelatihan dengan materi pengolahan dan penyajian makan pagi.

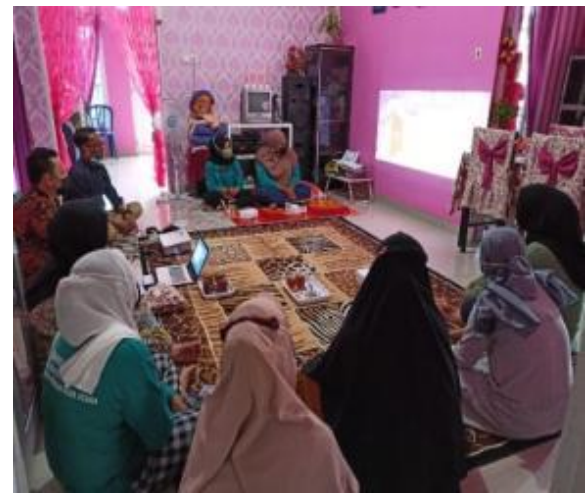

Gambar 7. Pelatihan Sajian Sarapan Pagi 
Pelatihan ini sebagai bentuk respon terhadap perlunya pengembangan variasi paket sarapan (breakfast) pada homestay di desa wisata mentawir. Kegiatan pelatihan ini memuat paket pelatihan breakfast nusantara dan kontinental. Selain mendorong pengelola desa wisata agar mampu mengolah paket breakfast kelokalan (nusantara), juga mendorong pengelola desa wisata mampu mengolah paket breakfast kontinental. Penyediaan paket breakfast kontinental merupakan upaya pemenuhan layanan bagi wisatawan mancanegara. Hasil dari pelatihan ini peserta mampu menyiapkan dan mengolah dua paket breakfast khas desa mentawir dan dua paket breakfast kontinental. Masingmasing kelompok pelatihan ini didampingi oleh nara sumber yang berasal dari tim pelaksana dan juga nara sumber ahli dari industri.

\section{Kegiatan Tahap 2}

a. Pengadaan perlengkapan safety berupa jaket pelampung untuk penyeberangan.

Untuk pemenuhan indikator dari klasfikasi desa wisata penerapan keselamatan wisatawan juga mejadi salah satu di dalamnya. Sehingga melalui kegiatan kepada masyarakat ini diberikan bantuan untukpengadaannya. Termasuk juga untuk peralatan protokol kesehatan yang lain yaitu alat pengukur suhu tubuh (thermo gun).

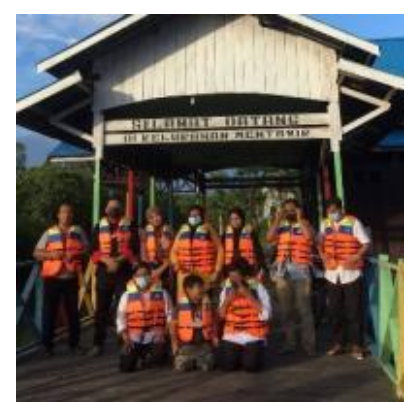

Gambar 8. Penyerahan Perlengkapan Safety Wisata Mentawir

b. Pendampingan dan kolaborasi dengan dinas Pariwisata PPU

Kegiatan pendampingan dilakukan secara sistematis dan berkesinambungan selama 3 hari berturut-turut mulai tanggal 1 - 3 September 2021. Pada hari pertama, tanggal 1 September 2021, kegiatan bertempat di Gedung Serba Guna Kelurahan. Kegiatan dihadiri oleh Kepala Dinas Pariwisata dan Kebudayaan Kabupaten Panajam
Paser Utara beserta jajarannya dan Lurah Mentawir beserta staf sehingga dan seluruh peserta dari mitra Selanjutnya pada hari yang sama kegiatan pendampingan dilanjutkan dengan diberikan materi tambahan tentang pengelolaan kelembagaan Pokdarwis yang efektif, efesien dan transparan melalui pembenahan administrasi atau pembukuan organisasi. Pada akhir sesi dilakukan diskusi secara berkelompok 
untuk melihat hasil-hasil dari tugas yang diberikan pada peserta pada saat pelatihan dan menyiapkan bahan dan

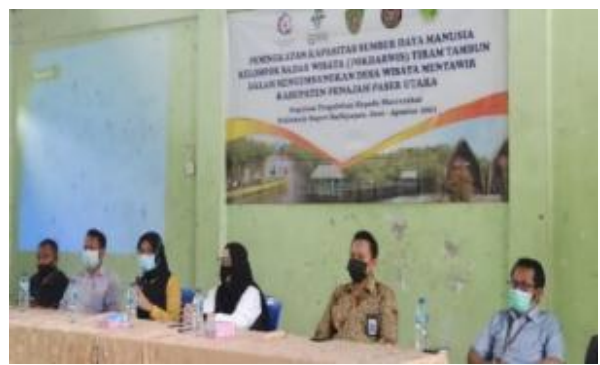

Gambar 9. Kolaborasi Materi Tim Pengabdian dengan Kepala Dinas Pariwisata PPU

Hari kedua, tanggal 2 September 2021, peserta kembali dibagi menjadi beberapa kelompok berdasarkan dari materi pelatihan yang diberikan. Pada kelompok pengelola dan pemandu desa wisata dilakukan pendampingan terhadap hasil hasil dari pengemasan

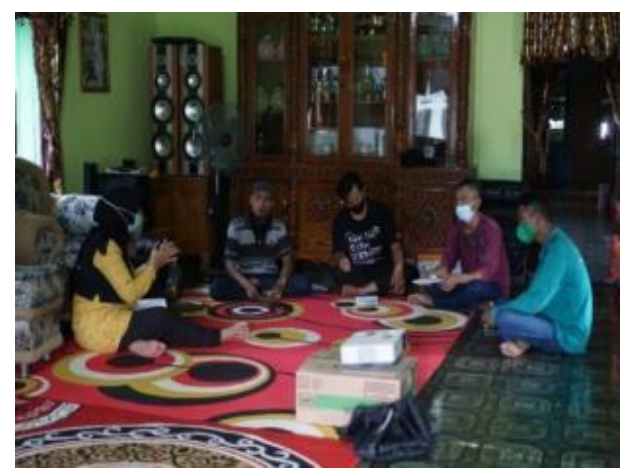

atraksi-atraksi wisata yang ada di desa Mentawir yang sudah dibuat menjadi beberapa paket wisata yang akan dicetak menjadi brosur serta dipromosikan baik secara langsung atau tidak langsung melalui media-media sosial yang telah dibuat oleh kelompok lain.

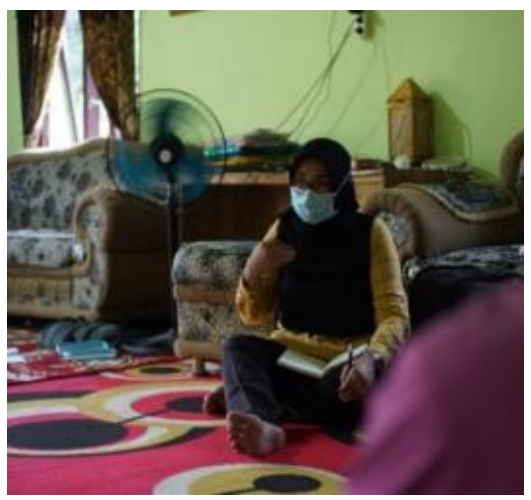

Gambar 10. Pemetaan Paket Wisata
Adapun paket-paket wisata
a. One day tour
Mentawir yang dihasilkan
sebagaimana berikut ini. 


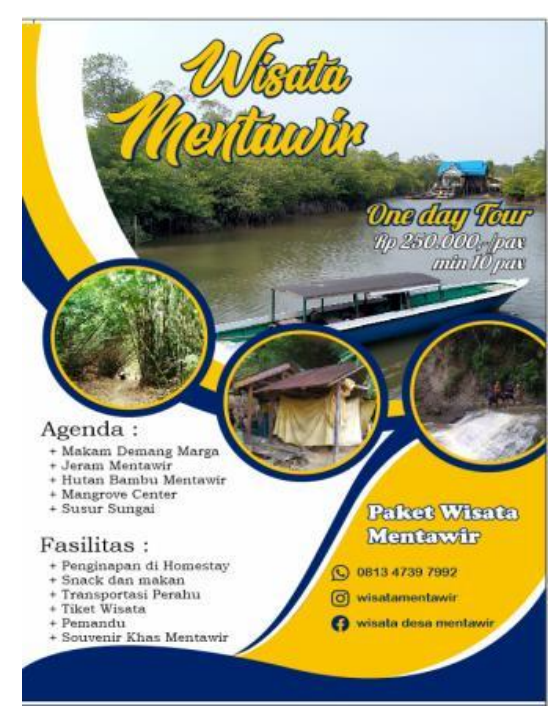

Gambar 11. Paket One Day Tour

Paket ini menawarkan atraksi-atraksi wisata yang ada di Desa Wisata Mentawir seperti makam Demang Marga, jeram sungai Mentawir, jelajah hutan bambu dan mangrove center serta susur sungai Tiram Tambun. Harga paket ini adalah $\mathrm{Rp}$ 250.000,-/orang sudah termasuk dengan 1 x snack dan makan siang dengan jumlah peserta minimal sebanyak 10 orang.

b. Two days tour $(2 D 1 N)$

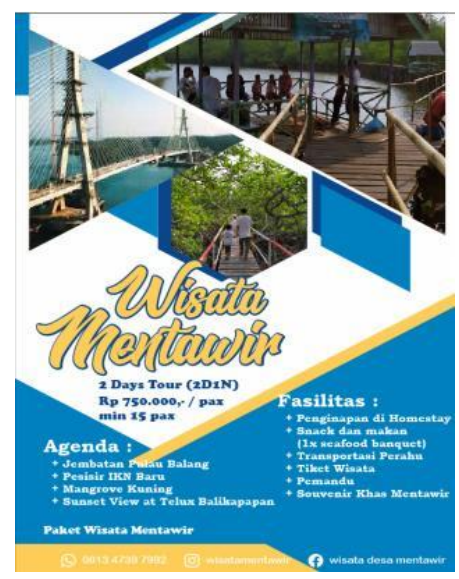

Gambar 12. Paket Two Days Tour

Paket ini menawarkan atraksiatraksi wisata wisata makam Demang Marga, jeram sungai Mentawir, jelajah hutan bambu, mangrove center, susur sungai Tiram Tambun sampai ke Teluk Balikpapan dengan atraksi tambahan jelajah Teluk Balikpapan dengan atraksi- atraksi wisatanya mangrove kuning, jembatan pulau balang dan pesisir lokasi IKN baru. Harga paket ini adalah Rp 700.000,- sudah termasuk snack dan makan malam seafood barbeque dengan jumlah peserta minimal 15 orang.

c. Three days tour $(3 D 2 N)$. 


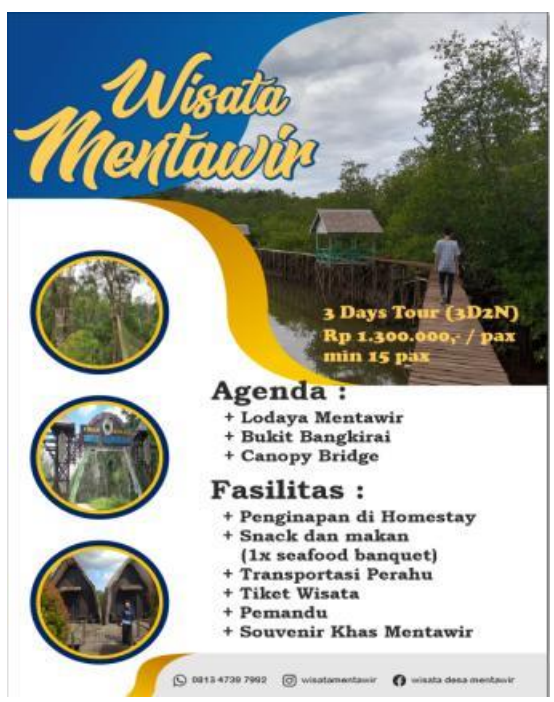

Gambar 13. Paket Three Days Tour

Paket ini menawarkan atraksiatraksi wisata seperti makam Demang Marga, jeram sungai Mentawir, jelajah hutan bamboo, mangrove center, susur sungai Tiram Tambun sampai ke Teluk Balikpapan dengan atraksi tambahan mangrove kuning, jembatan pulau balang dan pesisir lokasi IKN baru, rumah lodaya, bukit bangkirai dan canopy bridge. Harga paket ini adalah Rp 1.300.000,- sudah termasuk snack dan makan malam seafood barbeque dengan jumlah peserta minimal 15 orang. Pada akhir sesi akhir dihari kedua ini dilakukan pendampingan untuk praktek sebagai pemandu wisata (guide) dimana perwakilan peserta menjelaskan atau bercerita mengenai salah satu atraksi yang ada didalam paket wisata yang ditawarkan yaitu susur sungai tiram tambun dan mangrove kuning.
Pada kelompok pengelola pemasaran/ promosi medsos kegiatan penfampingan yang dilakukan mengahsilka beberapa akun media social baru yaitu Youtube Channel, Facebook, Instagram Bisnis. Dalam sesi pendampingan mitra dikenalkan bagaimna malakukan branding secara digital melalui media sosial Kawasan Mentawir afgar dikenal oleh masyarakat luas. Dalam kesempatan tersebut dikenalkan beberapa aplikasi khusus yang bisa digunakan untuk edit video maupun foto. Pada dasarnya anak- anak muda kelurahan Mentawair sudah memiliki literasi digital yang cukup baik. Hanya saja terkendala kekuatan jaringan internet yang memang masih lemah. Mitra diberikan kesadaran tentang potensi media sosial tidak saja untuk branding, tapi juga untuk produktifitas ekonomi. 


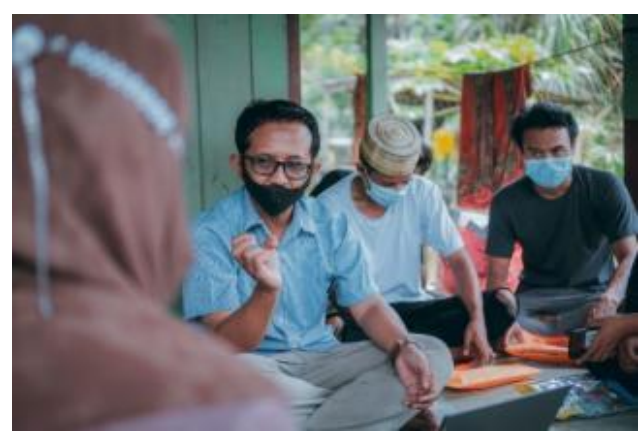

a. Diskusi Digital Branding

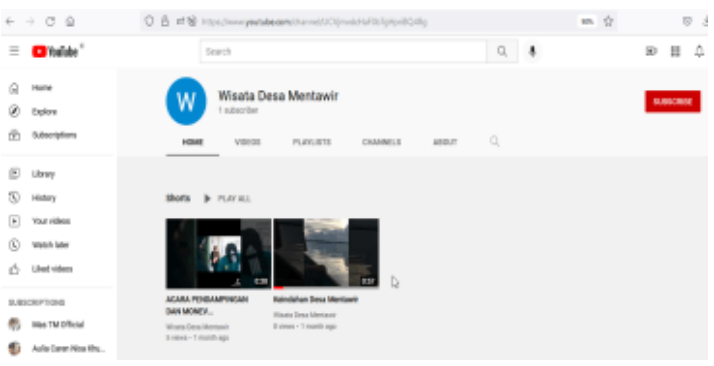

c. Youtube channel wisata Mentawir

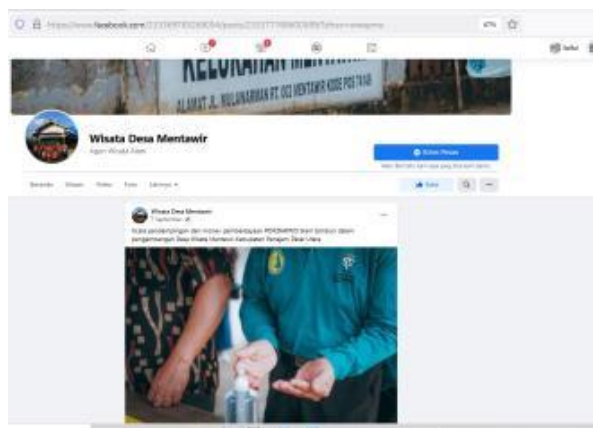

b. Akun Facebook

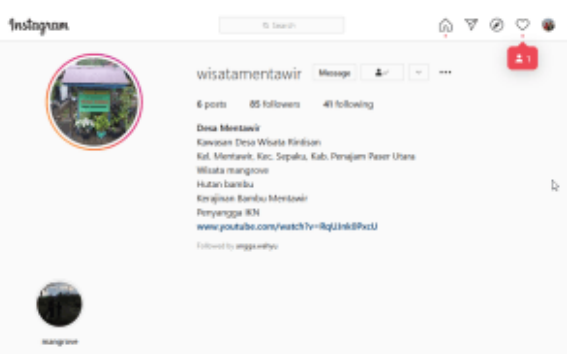

d. Akun IG @Wisatamentawir

Gambar 14. Pendampingan Digital Branding melalui Media Sosial

Dalam upaya menambah kemampuan pengelola homestay dalam penyediaan menu sarapan yang lebih bervariasi maka pedampingan yang dilakukan adalah mengolah sarapan menu sarapan kontinental yang praktis dan bisa memanfaatkan olahan lokal yang ada di Mentawir seperti sirup buah mangrove. Produk sarapan yang dibuat yakni classic waflle, fruit waffle with mangrove sirup dan bread toast dengan berbagi varian isi.
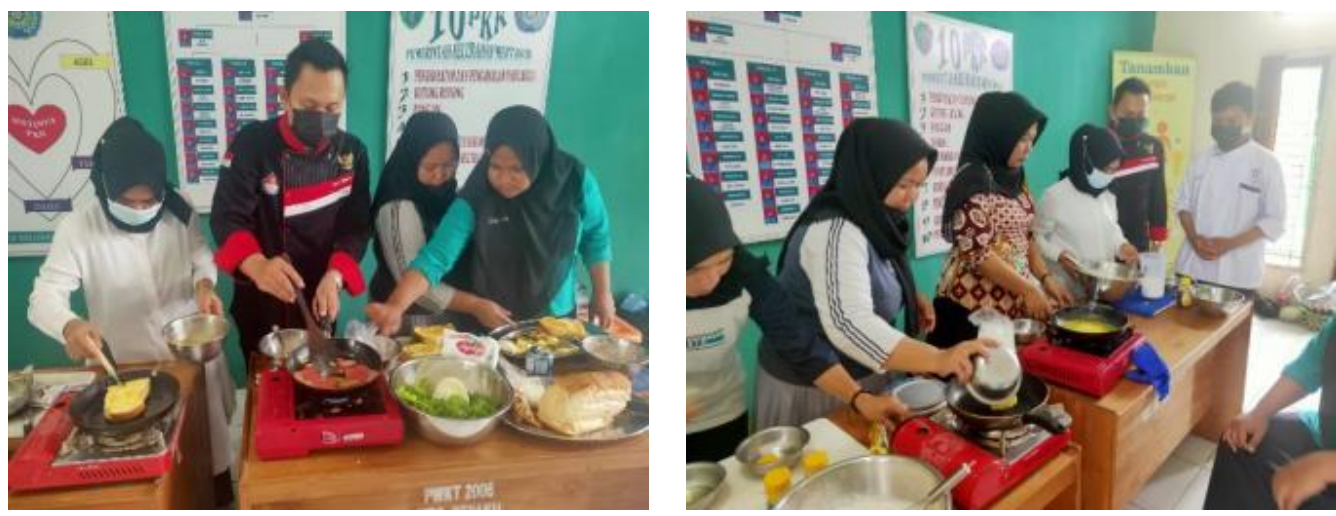

Gambar 15. Pembuatan Menu Sarapan Pagi Kontinental

Hari ketiga, tanggal 3 Septemberr 2021, dilakukan pendampingan dalam pengelolaan kelembagaan Pokdarwis yang efektif, efesien dan transparan khususnya untuk membenahi administrasi dan pembukuan dari Pokdarwis Tiram Tambun. 
Pada akhir pelaksanaan kegiatan pengabdian kepada masyarakat ini dilakukan evaluasi terhadap hasil-hasil yang telah dicapai oleh setiap kelompok sebagai masukan untuk nantinya setelah selesai kegiatan bisa untuk terus dilakukan perbaikan dan peningkatan yang lebih baik serta dilakukan serah terima peralatan praktek pembuatan sarapan continental dan peralatan protokol kesehatan kepada Ketua Pokdarwis Tiram Tambun untuk menjadi inventaris kelompok yang bisa dipergunakan bersama-sama nantinya.

\section{PENUTUP}

\section{Kesimpulan}

Dari kegiatan pengabdian kepada masyarakat yang sudah dilaksanakan untuk pemberdayaan Pokdarwis "Tiram Tambun" dalam pengembangan Desa Wisata Mentawir dapat disimpulkan beberapa hal. Pertama, pengetahuan dan ketrampilan pengurus dan anggota Pokdarwir Tiram Tambun menjadi bertambah atau meningkat dalam hal pengelolaan kelembagaannya yang efektif, efesien dan transparan melalui pembenahan administrasi atau pembukuan organisasi . Kedua, pengembangan potensi kepariwisataan di desa wisata Mentawir dapat dipetakan melalui produk wisata dalam bentuk paket-paket wisata yang akan ditawarkan kepada wisatawan. Ketiga, meningkatnya atau bertambahnya promosi desa wisata Mentawir melalui berbagai media sosial dalam rangka meningkatkan jumlah wisatawan yang berkunjung kesana.

\section{Saran}

Dari kesimpulan yang diambil dari hasil kegiatan pengabdian kepada masyarakat yang telah dilaksanakan maka dapat diberikan beberapa saran untuk perbaikan ataupun kelanjutannya. Pertama, untuk mitra dalam hal ini Pokdarwis "Tiram Tambun" agar dapat selalu menjalin komunikasi dan berkoordinasi antara pengurus dan anggotanya dalam pengelolaan kelembagaan serta selalu melaksanakan administrasi dan pembukuan organisasinya dengan baik. Selalu mengembangkan dan memperbaharui berbagai media yang digunakan untuk mempromosikan desa wisata Mentawir serta menjalin kerjasama dengan tourtour operator guna menjual dari paketpaket wisata yang ada. Kedua, untuk pemangku kepentingan yang membidangi bidang kepariwisataan baik yang berhubungan secara langsung ataupun tidak langsung dengan Pokdarwis "Tiram Tambun" dapat selalu memperhatikan dan menindaklanjuti gagasan / ide ide serta saran saran dari organisasi binaannya dengan baik melihat besarnya minat masyarakat untuk dapat mengembangkan potensi pariwisata di wilayahnya. Ketiga, kegiatan pengabdian kepada masyarakat ini dapat terus berlanjut dengan melihat antusiasme dan semangat mitra untuk bisa mengembangkan desa wisatanya ke klasifikasi yang lebih tinggi.

\section{DAFTAR PUSTAKA}

Ambar Teguh Sulistiyani. 2004. Kemitraan dan Model-Model Pemberdayaan. Yogyakarta: Gaya Media. 
Argyo Dermantoto. 2009. Pembangunan

Pariwisata Berbasis Masyarakat.

Surakarta: Sebelas Maret

University Press.

Gunawan Sumodiningrat. 2009.

Mewujudkan Kesejahteraan

Bangsa: Menanggulangi

Kemiskinan dengan Prinsip

Pemberdayaan Masyarakat.

Jakarta: Elex Media Komputindo.

Mardi Yatmo Hutomo. 2000.

Pemberdayaan Masyarakat dalam

Bidang Ekonomi: Tinjauan

Teoritis dan Implementasi.

Jakarta: Bappenas.

Pantiyasa, I Wayan. 2021.

Pemberdayaan Masyarakat

Berbasis Pendampingan Melalu

Pelatihan CHSE Di Desa Kaba-

Kaba, Tabanan, Bali. Vol 01 No

01, 2021: 1-10

Soemarno. 2010. Desa Wisata.

(http://marno.lecture.ub.ac.id/files

/2012/01/Desa-wisata.doc. diakses

28 Oktober 2021)

Sri Najiati, Agus Asmana, I Nyoman N.

Suryadiputra. 2005.

Pemberdayaan Masyarakat di
Lahan Gambut. Bogor: Wetlands Internasional.

Sumaryadi. 2005. Perencanaan Pembangunan Daerah Otonom dan Pemberdayaan Masyarakat. Jakarta: Citra Utama

Suryo Sakti Hadiwijoyo. 2012. Perencanaan Pariwisata

Pedesaan Berbasis Masyarakat (Sebuah Pendekatan Konsep). Yogyakarta: Graha Ilmu.

Triyono, A. 2014. Pemberdayaan masyarakat melalui community development program posdaya (pos pemberdayaan keluarga) pt. Holcim imdonesia". Jurnal Komuniti, 6 (01), 111-121.

Yoeti, O. A. 2013. Komersialisasi seni budaya dalam pariwisata. Bandung. Angkasa

Yulianti, Devi. 2021. Kemitraan Antar Stakeholders

Dalam Pengembangan Agrowisata Di Desa Sungai Langka Kabupaten Pesawaran. Administrativa: Jurnal Birokrasi, Kebijakan dan Pelayanan Publik. ISSN 27147673 